\title{
The Impact of the Amendment of Taiwan's Certified Public Accountant Act in 2007 on Large Accounting Firms
}

\author{
Chung-Cheng Yang ${ }^{1}$, Jianxiong Chen ${ }^{1, *}$ and Wen-Chi Yang ${ }^{2}$ \\ 1 Department of Accounting, National Yunlin University of Science and Technology, Yunlin 64002, Taiwan; \\ ycc@yuntech.edu.tw \\ 2 Department of International Business, Tamkang University, New Taipei 251301, Taiwan; \\ 406590124@s06.tku.edu.tw \\ * Correspondence: d10825001@gemail.yuntech.edu.tw
}

Citation: Yang, C.-C.; Chen, J.; Yang, W.-C. The Impact of the Amendment of Taiwan's Certified Public Accountant Act in 2007 on Large Accounting Firms. Sustainability 2021, 13, 1229. https://doi.org/10.3390/ su13031229

Academic Editor: Benedict Sheehy Received: 19 November 2020

Accepted: 11 January 2021

Published: 25 January 2021

Publisher's Note: MDPI stays neutral with regard to jurisdictional claims in published maps and institutional affiliations.

Copyright: (c) 2021 by the authors. Licensee MDPI, Basel, Switzerland. This article is an open access article distributed under the terms and conditions of the Creative Commons Attribution (CC BY) license (https:// creativecommons.org/licenses/by/ $4.0 /)$.

\begin{abstract}
Taiwan's Financial Supervisory Commission of the Executive Yuan promulgated the fully amended Certified Public Accountant Act in 2007, which directly led to significant changes in accounting law. From the perspective of the economic theory of law, this study investigates the amendment of the Certified Public Accountant Act resulting in an increase or decrease in the overall revenue and different revenue shares of accounting firms, and puts forward measures that should be taken by accounting firms and stakeholders. We focus on large accounting firms and divide the sample period into before and after 2008. This study uses the translog revenue function and revenue share functions of the public accounting industry, and based on the 1989-2017 Survey Report of Audit Firms in Taiwan, and we find that the amendment of the Certified Public Accountant Act has had a positive effect on overall revenue, increasing overall revenue and the overall management advisory services shares, and in reducing the overall accounting and auditing shares and tax services shares of large accounting firms. Additional analyses provide regulators with public policy implications and provide accounting firms with managerial information.
\end{abstract}

Keywords: law; accounting firm; certified public accountant act; revenue

\section{Introduction}

After the accounting scandals of Enron and WorldCom, the professional ability and independence of accountants was questioned, and the relevant agencies responsible for formulating accounting laws in many countries amended and updated accounting laws. Among them, the United States promulgated the Sarbanes-Oxley Act in June 2002, and established a full-time Public Company Accounting Oversight Board (PCAOB) to better strengthen supervision and guidance of accounting firms. The aim of this was to increase the independence of accountants and clarify the accountant's responsibilities in the hope of restoring the investing public's confidence in the capital market. These measures issued by the United States also prompted the developed markets, such as the United Kingdom, Japan, and Australia, to follow suit, actively adjust their accounting laws, and strengthen the supervision of the public accounting industry.

The frequent occurrence of audit failure cases has also alerted the public accounting industry of Taiwan, to these concerns. With the gradual internationalization of Taiwan's capital market, the business and responsibilities of Taiwan's accountants are considerably increasing. Some of the original accounting laws are out-of-date. In order to: (1) promote the integration of Taiwan's accounting laws with the international developed markets; (2) improve the practice environment and quality of accountants; (3) enhance the performance of accountants' professional functions; and (4) provide open and transparent accounting information for all stakeholders, Taiwan's Financial Supervisory Commission (FSC) of the Executive Yuan referred to the accounting management system of developed markets and the changes of the environment for domestic accounting practice. After 
seven years of research, Taiwan's FSC of the Executive Yuan finally promulgated the fully amended Certified Public Accountant Act on 26 December 2007.

As a social structure, accounting is affected not only by rule amendments, but also by the change of the structure of the rule-making field [1]. In today's open society, the implementation of accounting reform is inevitable [2] as no two countries in the world have the same accounting laws, especially between developed markets and emerging markets. Simply stated, there are significant differences in accounting laws between the United States and Mexico even though they are not geographically far apart [3]. Meanwhile, as well-documented in accounting literature, the differences as such are reflected in the following major factors, e.g., political and economic systems and historical origins, accounting profession, accounting education, financial sources, taxation, culture, economic development level [3-6]. However, we assume that the different requirements of accounting information quality in different countries are the main factors when it comes to the explanations made to deal with the differences of accounting laws in different countries.

The quality of accounting information has a significant impact on the decision-making and judgment made by those who use the financial information, and the development of accounting firms is closely associated with the quality of accounting information. Therefore, research on the impact of Taiwan's new Certified Public Accountant Act on the development of accounting firms highlights the significance of its practical purpose. In the past few decades, revenue management has developed into a universal and indispensable methodological framework [7]. A plethora of research has been conducted into the connection between different types of revenue and independence of accounting firms [8-10]. We draw upon past experiences and focus on the impact of the new Certified Public Accountant Act on accounting firms' revenue among the many effects this has on accounting firms. Given the fact that large accounting firms occupy most of the market share in Taiwan, the new Certified Public Accountant Act mainly affects large accounting firms. Therefore, this paper attempts to use the revenue function in economic theory to explore the impact of Taiwan's amendment of the Certified Public Accountant Act on the revenue of large accounting firms, i.e., whether legal changes enhance the sustainability of accounting firms' revenue. In doing so, the public accounting industry regulators and the public accounting industry policy-making departments provide a reference basis.

This study adopted annual pooling data of large accounting firms for the period 1989-2017 to undertake an empirical analysis of accounting firms. The revenue of Taiwan's accounting firms is mainly composed of accounting and auditing $(A \mathcal{E} A)$, tax services (TAX), and management advisory services (MAS), so the impact of the new Certified Public Accountant Act on accounting and auditing shares $(A \mathcal{E} A \%)$, tax services shares $(T A X \%)$ and management advisory services shares $(M A S \%)$ is also included in this reported research. In addition, an additional analysis of the impact of factors such as $A \mathcal{E} A, T A X, M A S$, different human resources and the big four accounting firms (Big 4) on firms' revenue are also taken into account to suggest regulators evaluate the long-term impact of new Certified Public Accountant Act on the development of firms from the perspective of revenue, and consider the further amendment of the Act to promote the healthy development of the public accounting industry.

While the impact of the amendment of accounting law on the financial environment of corporations and institutions cannot be denied, scholars have yet to examine the significant effect the amendment of accounting law has on revenue of accounting firms. Existing relevant literature mainly discusses the impact of the amendment of other laws, for example, the Tax Reform Act [11-14], IFRS16 [15-17], the Securities Act [18], etc. At present, there are only two studies in the literature related to the impact of the amendment of accounting law, although some scholars have focused on the legal effect amendment that accounting law has on cash accounting information systems [19] or on the division of accounting firms [20]. However, the amendment of accounting law as a general phenomenon has not attracted scholarly attention. In light of its power to impact accounting firms, this article 
calls attention to the negative effects that the amendment of accounting law may have on the firm's revenue, and suggests measures to neutralize them.

Accounting firms are known as "gatekeepers of the capital market" and play a very important role in the transparent disclosure of corporate accounting information. Therefore, it is important to study the impact that the amendment of the Certified Public Accountant Act has had on accounting firms. Our theory and findings make several contributions. First, to the best of our knowledge, we have pioneered the survey report research of this kind using a public accounting industry revenue function in accounting research to study the impact of changes in the Act. There is no existing literature on the impact of the amendment of the accounting law on the revenue of the public accounting industry. This article will fill this gap in the literature. Second, revenue has a significant impact on the survival and development of firms [21-23]. From the perspective of revenue in economic theory, by discussing the amendment of accounting law and their effects on accounting firms, we find that the amendment of the Certified Public Accountant Act has had a positive effect on overall revenue, increasing overall revenue and the overall management advisory services shares, and in reducing the overall accounting and auditing shares and tax services shares of large accounting firms. Our results provide an important reference for accounting firms to increase their revenue after the amendment of the Certified Public Accountant Act. Third, according to our research, accounting policymakers can further amend the Certified Public Accountant Act and formulate more suitable public accounting industry policies. We put forward specific measures for the regulators of the public accounting industry to consider, and we put forward matters that should be paid attention to for stakeholders such as clients, creditors, and partners of accounting firms. In the aforementioned ways, this promotes the development of firms and safeguard the interests of stakeholders.

Our findings, however, must be interpreted with caution. Our findings, based on Taiwan's data, may not be generalizable to U.S. public accounting industry, due to institutional differences. We note, however, that Chen et al. [24] and Chi et al. [25] both report that accounting and auditing standards in Taiwan are similar to those in the United States, and important empirical regularities (e.g., [26]) documented in the U.S. public accounting industry also occur in the Taiwan's public accounting industry $[27,28]$. Thus, there are significant similarities between Taiwan and the United States, making our findings relevant for the U.S. public accounting industry. In addition, we call for future research to further investigate the impact of accounting law amendments on the firms from other perspectives, as well, such as the cost's perspective.

The remainder of this paper is organized as follows. Section 2 deals with the background and development of this research hypothesis. In Section 3, provides theoretical model, estimation model, data and variables of this study, and the empirical results are included in Section 4. Section 5 is concerned with additional analyses of this reported research. Finally, in Section 6, we summarize the impact of our findings on the public accounting industry and provide suggestions for managers.

\section{Background and Hypothesis Development}

Researchers and policy makers have long been interested in the issuance or amendment of laws. Many studies have been mainly conducted to analyze the industry data and government data. (These include studies of the Tax Reform Act [11-14], the Economic Recovery Tax Act [29-31], IFRS16 [15-17], the Securities Act [18], the America Invents Act [32,33], the American Recovery and Reinvestment Act [34,35], the American Jobs Creation Act [36,37], the Sherman Act [38], the Taxpayer Relief Act [39-41], the Glass-Steagall Act [42], the Gramm-Leach-Bliley Act [43], and the Omnibus Trade and Competitiveness Act [44].) The focus of these studies is on the significant impact of the promulgation or amendment of laws on society or related industries.

The issuance and replacement of audit-related laws also has a significant impact on the public accounting industry. Among them, the most far-reaching influence is the Sarbanes-Oxley Act (SOX) issued by the Congress and the government of the United States, 
which was accelerated by the scandal concerning Enron, the largest energy company in the United States, in December 2001. SOX has made a historic change in the norms of the public accounting industry. $\mathrm{Li}$ [10] found a change in the correlation between audit (and total) fees and going concern opinions, i.e., from no correlation at all in 2001 to a positive correlation in 2003. This part of the findings indicates that auditors have become more conservative after the promulgation of SOX. Dezoort et al. [45] based on the empirical materials obtained from 372 audit committee members of listed companies, found that after the promulgation of SOX, audit committee members have more responsibility for solving accounting problems. At this time, audit committee members have more professional knowledge of the evaluation of accounting issues, and are more concerned about the accuracy of financial statements in comparison with that associated with the SOX before. Moreover, Defond and Lennox [46] found that more than 600 low-quality auditors withdrew from the market after the SOX was promulgated. In other words, the audit quality of American auditors has been improved with the withdrawal of low-quality auditors from the market after the implementation of SOX. Huang et al. [47] used both fee-levels and fee-change models and found that the Big 4 became more conservative in the post-Sox period with respect to client acceptance and pricing decisions; i.e., controlling for audit and client characteristics, audit fee levels rose approximately $74 \%$ in the post-SOX period. Non-audit fees fell significantly over the same period, but total fees paid to auditors rose because the audit fees increased more than those paid to offset the decline in non-audit fees. The significant impact of SOX on the public accounting industry of developed markets encourages us to have a strong interest in studying the impact of the comprehensive amendment of the Certified Public Accountant Act of Taiwan, which was carried out in 2007, on the public accounting industry.

In December 2018, South Korea amended its Certified Public Accountant Act. One of the key changes was its allowance of divisions and mergers after the division of accounting firms. While the division of a company aims to separate assets and sales, the division of an accounting corporation aims to separate its partners and to succeed in its audit contracts. The amendment adopted divisions and mergers after the division of accounting corporations in order to facilitate restructuring of accounting corporations [20]. The 29th amendment to the Act on Accounting of the Czech Republic brought extensive changes, one of them being the legalization of cash accounting. The statement of reasons for this amendment refers to the demand for cash accounting from small accounting entities. Šimíková [19] analyses its development and assesses the new concept of cash accounting. At present, the only two related studies in the literature mentioned above do not involve the impact of the amendment of accounting law on the revenue of accounting firms. The revenue of accounting firms is directly related to the survival or death of firms, which has a significant impact on the whole social economy. Therefore, from the perspective of accounting firm's revenue, this study explores the impact of accounting law amendments on accounting firm's revenue.

Since the amendment of Taiwan's Certified Public Accountant Act was implemented, the new Certified Public Accountant Act has broadened the scope of accounting practice (for example, accountants can act as administrative litigation agents in tax-related cases). Therefore, we believe that the overall revenue of accounting firms would increase after the implementation of the amendment of the Certified Public Accountant Act. At the same time, several empirical studies using audit client-level data have documented that the extralarge accounting firms tend to order more than proportional revenue from their services relative to the other accounting firms [48-52]. In addition, the Big 4 usually occupies the majority of the market share [53], so we believe the overall revenue improvement was to a greater extent in the Big 4. Consequently, we proposed the first hypothesis of this study as follows:

Hypothesis 1 (H1). Ceteris paribus, the amendment of the Certified Public Accountant Act has had a positive effect on the revenue of large accounting firms, and to a greater extent for Big 4. 
The new Certified Public Accountant Act stipulates that "accountants who are engaged in management advisory services or others that may affect their independence shall not undertake the audit of financial reports." In the meantime, the new Certified Public Accountant Act conducts differentiated management of accounting firms by referring to the relevant laws of the United States and Japan. From the perspective of safeguarding public rights and interests and promoting social integrity, the new Certified Public Accountant Act for the first time requires the accounting authorities to inspect accounting firms with $A \mathcal{E} A$ qualification, and stipulates that accounting firms shall not evade, hinder or refuse inspection. Strict supervision lead to firms more cautious [54]. In view of the strict supervision of $A \mathcal{E} A$ under the new Certified Public Accountant Act, we expect accounting firms to appropriately reduce $A \mathcal{E} A$ shares under severe regulatory pressure. In other words, the new Certified Public Accountant Act would possibly reduce $A \mathcal{E} A \%$ of accounting firms. However, because Big 4 has relatively good $A \mathcal{E} A$ normativity, we expect the aforementioned situation to be lesser in the Big 4. Based on these arguments, we specifically proposed the following hypothesis:

Hypothesis 2 (H2). Ceteris paribus, the amendment of the Certified Public Accountant Act reduces the overall $A \mathcal{E} A \%$ of large accounting firms, but to a lesser extent for the Big 4.

The government must commit itself to making wise use of limited material and human resources [55] Enterprises also need to make full use of various resources and utilize the most needed resources in the most profitable business. The opportunity cost theory shows that when a specific human resource is occupied by a certain business, it will lose the potential revenue of that human resource in another business [56]. The new Certified Public Accountant Act stipulates that accountants can act as agents of tax administrative litigation, and this therefore enables accounting firms to open another source of revenue. As accountants can obtain a larger revenue when they act as tax agents, this regulation will inevitably cause firms to allow more tax experts to act as tax agents to obtain better revenue, and the number of professionals engaged in $T A X$ will be reduced, and so is the revenue share on TAX. However, by providing more attractive career opportunities and better pay, larger firms tend to attract more productive employees [57,58], and the Big 4 have attracted many TAX experts, and a large number of high-quality tax experts can usually cover both tax administrative litigation agency business and TAX. Therefore, we expect the above situation to a lesser extent in the Big 4. This suggests the following hypothesis:

Hypothesis 3 (H3). Ceteris paribus, the amendment of the Certified Public Accountant Act reduces the overall TAX\% of large accounting firms, but to a lesser extent for the Big 4.

The total revenue of accounting firms is mainly composed of $A \mathcal{E} A$ revenue, $T A X$ revenue and $M A S$ revenue. The new Certified Public Accountant Act has strengthened the supervision of $A \mathcal{E} A$ and TAX of accounting firms. We posit that, $A \mathcal{E} A \%$ and TAX\% of accounting firms will decline to an greater extent after the implementation of the amendment of the Certified Public Accountant Act, and accounting firms $M A S \%$ will increase due to the aforementioned situation and the strong growth of Taiwan's management advisory market. However, after the implementation of the new Certified Public Accountant Act, the Big 4 rely heavily on their own financial resources to establish management advisory companies in order to divest most of the MAS. Therefore, we posit that the implementation of the amendment of the Certified Public Accountant Act will give rise to a decrease in the Big 4's $M A S \%$. Accordingly, we therefore hypothesize:

Hypothesis $4 \mathbf{( H 4 ) . ~ C e t e r i s ~ p a r i b u s , ~ t h e ~ a m e n d m e n t ~ o f ~ t h e ~ C e r t i f i e d ~ P u b l i c ~ A c c o u n t a n t ~ A c t ~}$ increased the overall MAS\% of large accounting firms, but the MAS\% of the Big 4 decreased. 


\section{Method}

\subsection{Theoretical Model}

Yang, Tsai, and Fu [59] indicated that the operation of accounting firms is mainly based on human resources, providing audit and non-audit services. Human resources are divided into two main types: quality and quantity. Regarding the quality of human resources, accounting practitioners form human capital to provide high-quality services through professional education, training, and experiences accumulated from work. In the case of quantity, partners lead professional accountants, such as managers, professional in-charge accountants and assistants in providing $A \mathcal{E} A, T A X$, and $M A S$, and charging $A \mathcal{E} A$, TAX and MAS service fees, and this is the source of accounting firms' revenue.

Greene [60] noted that most current research employing production, cost, revenue, and profit functions typically uses a flexible functional form because this form can facilitate the analysis of some complex characteristics of these functions, such as elasticities of substitution and the effects of the second derivatives of the function, while these restrictions do not exist for log-linear models (i.e., Cobb-Douglas model). The most popular flexible functional form is the translog model, which is often interpreted as a second-order approximation to an unknown functional form. In addition, an approach commonly used for estimating a multiple output and input production correspondence is to specify a translog model $[61,62]$. The translog revenue function is a logarithmic second order approximation of the reduced form revenues function $\mathrm{R}(\mathrm{W}, \mathrm{Z})$ where $\mathrm{W}$ is a vector of input prices and $\mathrm{Z}$ a vector of output characteristics. The translog function is capable of representing varying levels of revenue elasticities [63]. Vessel level data for the Norwegian whitefish fisheries for the period 1995-2007 is used to showcase the application of the model [64]. Banker et al. [65] creatively studied the public accounting industry through the translog revenue function. We set the translog revenue function for the public accounting industry, and established the revenue share model of various services as follows [66]:

$$
\begin{aligned}
\ln r=\alpha_{0}+\sum_{i=1}^{3} \alpha_{i} \ln p_{i} & +\sum_{j=1}^{3} \beta_{j} \ln h_{j}+\sum_{k=1}^{2} \gamma_{k} \ln x_{k}+\frac{1}{2} \sum_{i=1}^{3} \sum_{l=1}^{3} \alpha_{i l} \ln p_{i} \ln p_{l}+\frac{1}{2} \sum_{j=1}^{3} \sum_{m=1}^{3} \beta_{j m} \ln h_{j} \ln h_{m} \\
& +\frac{1}{2} \sum_{k=1}^{2} \sum_{n=1}^{2} \gamma_{k n} \ln x_{k} \ln x_{n}+\sum_{i=1}^{3} \sum_{j=1}^{3} \delta_{i j} \ln p_{i} \ln h_{j}+\sum_{i=1}^{3} \sum_{k=1}^{2} \theta_{i k} \ln p_{i} \ln x_{k} \\
& +\sum_{j=1}^{3} \sum_{k=1}^{2} \pi_{j k} \ln h_{j} \ln x_{k}
\end{aligned}
$$

In Equation (1), $\alpha_{i}, \alpha_{i l}, \beta_{j}, \beta_{j m}, \gamma_{k}, \gamma_{k n}, \delta_{i j}, \theta_{i k}, \pi_{j k}$ are parameter, $r$ stands for the revenue of accounting firms, $p_{1}$ stands for the average accounting and auditing price, $p_{2}$ stands for the average tax services price, $p_{3}$ stands for the average management advisory services price, $h_{1}$ stands for the average number of years of education, $h_{2}$ stands for the total employee training expenses, $h_{3}$ stands for the average number of years of experience, $x_{1}$ stands for the total number of partner accountants, $x_{2}$ stands for the total number of professional accountants. Linear homogeneity in output prices implies that a proportionate increase in all output prices must result in the same proportionate increase in total revenue for given input levels. This imposes the following restrictions on (1):

$$
\sum_{i=1}^{3} \alpha_{i}=1, \sum_{i=1}^{3} \alpha_{i l}=0, \sum_{i=1}^{3} \delta_{i j}=0, \sum_{i=1}^{2} \theta_{i k}=0
$$

Differentiate $\ln p_{i}$ according to (1) and we can employ Shephard's [67] Lemma to obtain $\left(\partial r(\cdot) / \partial p_{i}=y_{i}\right)$, we can derive the revenue share of each service as follows:

$$
r_{i} \%=\alpha_{1}+\sum_{i=1}^{3} \alpha_{i l} \ln p_{l}+\sum_{i=1}^{3} \delta_{i j} \ln h_{j}+\sum_{i=1}^{3} \theta_{i k} \ln x_{k}, \text { for } i=1,2,3 .
$$

In Equation (3), $r_{1} \%=p_{1} y_{1} / r=\partial \ln r / \partial \ln p_{1}$ stands for $A \mathcal{E} A \%, r_{2} \%=p_{2} y_{2} / r=$ $\partial \ln r / \partial \ln p_{2}$ stands for $T A X \%$ and $r_{3} \%=p_{3} y_{3} / r=\partial \ln r / \partial \ln p_{3}$ stands for $M A S \%$. 
The translog revenue model in (1) is then estimated together with the endogeneity conditions represented in (3).

\subsection{Data and Variables}

\subsubsection{Data Source and Sample Period}

The annual pooling data used in this study was obtained from the "1989-2017 Survey Report of Audit Firms in Taiwan" issued by Taiwan's FSC of the Executive Yuan. While the publication of this report was handled by the Ministry of Finance starting in 1989, the FSC assumed responsibility for relevant survey work in 2004. The report's goals include the promotion of business modernization and the development of service industries in keeping with government policies, the understanding of the business status and directions of accounting firms, the establishment of basic statistical data concerning accounting firms, and the provision of this information as a basis for the government's drafting of relevant economic policies and as a reference for accounting firms. Due to the fact that the new Certified Public Accountant Act mainly affects large accounting firms, only these large accounting firms were selected as the sample of this study. Article 4 of Taiwan's "Regulations Governing Approval of Accountants to Audit and Attest to the Financial Reports of Public Companies" states that: "Those accountants performing the audit and attestation of public enterprises' financial reports, and those joint or corporate accounting firms to which they belong, shall consist of at least three accountants, among whom, there should be no fewer than two accountants holding at least three years of practice or actual participation assisting in the implementation of attestation work, and there should be no fewer than six audit assistants; and they must possess a common office location." We used this type of accounting firm as the standard for identifying large accounting firms in this study and classified other accounting firms without public enterprise attestation income as small/medium accounting firms.

To reflect the research variables and to maintain data integrity, this study consequently selected a total of 29 fiscal years between 1989 and 2017 as the sample period and discarded unreasonable observations, such as when an accounting firm has public offering income but is a sole proprietorship or has fewer than 3 partners. Otherwise, cases in which data copying errors or omissions may have caused the data to be zero were discarded; for instance, when a firm had income for an entire year, but the number of employees or partners was zero. This data deletion work ensured that the research data better reflected the actual situation of accounting firms. Following the deletions, the data consisted of 2210 observations (approximately $94.67 \%$ of all large accounting firm observations) covering 29 fiscal years.

\subsubsection{Variable Definitions}

In the theoretical model part, we explained the factors that affect the revenue of accounting firms based on the revenue function in economic theory. However, in order to explain whether the theory can explain the actual economic phenomenon, we verify it through the data from Taiwan's public accounting industry. Therefore, in this part, we need to select the proxy variables according to the theoretical variables in the Theoretical Model section.

As for the dependent variables of the study, we measured accounting firm total revenue ( $r$ ), including $A \mathcal{E} A$ revenue, TAX revenue, $M A S$ revenue. The sum of the three revenues is defined as the total revenue (REVENUE) [65]. The revenue function is derived from the profit maximization under the given firm's technology; therefore, the revenue is a function of the output price and input quantities [68].

In terms of independent variables, we used accounting firms $A \mathcal{E} A$ revenue, $T A X$ revenue and $M A S$ revenue to account for the proportion of total revenue as accounting firms $A \mathcal{E} A$ shares $(A \mathcal{E} A \%), T A X$ shares $(T A X \%)$ and $M A S$ shares $(M A S \%)$. In addition, we divided accounting firms $A \mathcal{E} A$ revenue, TAX revenue, and $M A S$ revenue by their respective quantities to obtain the average $A \mathcal{E} A$ price $\left(P \_A \mathcal{E} A\right)$, the average $T A X$ price 
$\left(P \_T A X\right)$ and the average MAS price (P_MAS) [65]. $P \_A \mathcal{E} A, P_{-} T A X$ and $P \_M A S$ are output prices of the public accounting industry.

In terms of human resources, human resources are divided into two main types: quality and quantity. First, the quality of human resources measures the human capital accumulated by accountants through professional education, training and experience. Professional education [69,70], training [71,72] and experience [72,73] affect the firm's revenue through audit quality. The proportion of the number of employees with different educational backgrounds to the total number of employees in accounting firms $\left(\mathrm{w}_{1}, \mathrm{w}_{2}, \mathrm{w}_{3}, \mathrm{w}_{4}, \mathrm{w}_{5}\right)$, is multiplied by the average number of years of schooling to obtain the qualification, and then the figures obtained are summed up to obtain the average number of years of education (EDUC). This study aimed to explore the impact of Taiwan's amendment of the Certified Public Accountant Act on large accounting firms. This concept took accounting firms as a whole into account and, therefore, the total employee training expenses (TRAIN) as the proxy variable was used for professional training. Prior studies indicate a positive association between employee experience and job performance [74]. In the auditing literature, some find a positive relationship between work experience and performance of proprietorship audit firms $[75,76]$. Job performance has a significant impact on the firm's revenue [77]. Based on prior studies [75,76,78,79], this study includes work experience of auditors (EXPER) to control its effects on revenue. After acquiring the academic qualifications in accounting, most professionals enter their careers as assistants in audit firms. They continue to learn and gain expertise through learning by doing. As for the measurement of experience, the average years of experience for partners and professional accountants are more than 10 years and 5-10 years, respectively [80]. After we conducted interviews with large accounting firms, we summarized the average years of working experience of partner accountants and professional accountants and calculated them. The average years were about 20 years and 6 years, respectively. We multiply these two figures by the proportion of the number of corresponding positions in the total number of employees $\left(\mathrm{x}_{1}, \mathrm{x}_{2}\right)$, and then sum up the obtained figures to obtain the average number of years of experience (EXPER) as the proxy variable of "experience" [81]. Second, for the measurement of the quantity of human resources, we used the total number of partner accountants (PARTNERS) and the total number of professional accountants (PROFESSION$A L S)$ as proxy variables. The aforementioned EDUC, TRAIN, EXPER, PARTNERS and PROFESSIONALS are input quantities of the public accounting industry. A limitation of the data is the lack of information on capital inputs. We do not consider capital inputs in our analysis as they are believed to be of secondary importance [82]. Also, Texas Society of Certified Public Accountants [83] national surveys of accounting practices larger than $\$ 1$ million in revenues indicate that rent, depreciation and occupancy costs amount to only about $6.5 \%$ of net revenue, whereas human resource compensation accounts for about $75.0 \%$ of net revenue. To the extent that omitted capital input variables are positively correlated with the included labor input variables, the estimated coefficients of these labor input variables are likely to be biased upward.

Taiwan promulgated the fully amended Certified Public Accountant Act on 26 December 2007, and we established the new Certified Public Accountant Act (CPA_Act) as a dummy variable. When its value is 1 , it indicates the year after the implementation of the amendment of Certified Public Accountant Act (including 2008); if its value is 0, it means the year before the implementation of the amendment of the Certified Public Accountant Act (including 2007), which was used to test the impact of the amendment of the Certified Public Accountant Act on the structure of the public accounting industry revenue. In addition, since the extra-large accounting firms command a premium for both audit and non-audit services $[48,50,52]$, and most of the market shares of Taiwan listed companies are occupied by Deloitte, KPMG, PWC, Ernst and Young. Big 4 is greatly influenced by the new Certified Public Accountant Act. Therefore, we added a dummy variable, Big 4, which equals one if the firm is one of the big four firms. We bring together the definitions of the above variables in Table 1 . 
Table 1. Variable definitions.

\begin{tabular}{|c|c|c|}
\hline \multicolumn{2}{|c|}{ Variable } & \multirow[b]{2}{*}{ Definition } \\
\hline $\begin{array}{l}\text { Theoretical } \\
\text { Variable }\end{array}$ & Proxy Variable & \\
\hline$r$ & REVENUE & Total revenue deflated to year 2017, expressed in million NT\$ \\
\hline$r_{1} \%$ & $A \mathcal{E} A \%$ & Proportion of accounting and auditing revenue \\
\hline$r_{2} \%$ & TAX\% & Proportion of tax services revenue \\
\hline$r_{3} \%$ & $M A S \%$ & Proportion of management advisory services revenue \\
\hline$p_{1}$ & $P \_A \mathcal{E} A$ & Average accounting and auditing revenue \\
\hline$p_{2}$ & P_TAX & Average tax services revenue \\
\hline$p_{3}$ & P_MAS & Average management advisory services revenue \\
\hline$h_{1}$ & $\overline{E D U C}$ & Employees' average number of years of education \\
\hline$h_{2}$ & TRAIN & Employee training expenses \\
\hline$h_{3}$ & EXPER & Employees' average number of years of experience \\
\hline$x_{1}$ & PARTNERS & Number of partners \\
\hline$x_{2}$ & PROFESSIONALS & Number of professionals \\
\hline \multicolumn{2}{|c|}{$C P A \_A C T$} & $\begin{array}{l}\text { A dummy variable that equals one if the year is one of the } \\
\text { years before } 2008 \text {, and } 0 \text { otherwise }\end{array}$ \\
\hline \multicolumn{2}{|c|}{ BIG4 } & $\begin{array}{l}\text { A dummy variable that equals one if the firm is one of the } \\
\text { Big four firms, and } 0 \text { otherwise }\end{array}$ \\
\hline
\end{tabular}

\subsection{Estimation Model}

Converted into the proxy variables through the theoretical variables mentioned above, we specified a translog function to represent the correspondence between the total revenue of public accounting firms, service prices, and human resource input. This relationship is mainly affected by factors such as $C P A \_A C T$. As mentioned above, these variables may affect the firm's service revenue share. Therefore, we used an annual pooling data for estimation, and added Big 4 into the model. In doing so, this dummy variable was used to investigate whether the new Certified Public Accountant Act will have different effects on the Big 4 versus the non-Big 4 . The translog revenue function in (1) can then be rewritten as the following equations:

Model 1: Revenue function estimation formula

$$
\begin{aligned}
& \text { In REVENUE }=\alpha_{0}+\alpha_{1} \ln P_{-} A \& A+\alpha_{2} \ln P_{-} T A X+\left(1-\alpha_{1}-\alpha_{2}\right) \ln P_{-} M A S+\beta_{1} \ln E D U C+\beta_{2} \ln T R A I N \\
& +\beta_{3} \ln \text { EXPER }+\gamma_{1} \ln \text { PARTNERS }+\gamma_{2} \ln \text { PROFESSIONALS }+\frac{1}{2} \alpha_{11}\left(\ln P \_A \& A\right)^{2} \\
& +\frac{1}{2} \alpha_{22}\left(\ln P_{\text {TAX }}\right)^{2}+\frac{1}{2} \alpha_{33}\left(\ln P_{\text {MAS }}\right)^{2}+\frac{1}{2} \beta_{11}(\ln E D U C)^{2}+\frac{1}{2} \beta_{22}(\ln \text { TRAIN })^{2} \\
& +\frac{1}{2} \beta_{33}(\ln \text { EXPER })^{2}+\frac{1}{2} \gamma_{11}(\ln \text { PARTNERS })^{2}+\frac{1}{2} \gamma_{22}(\ln \text { PROFESSIONALS })^{2} \\
& +\alpha_{12} \ln P_{-} A \& A \ln P_{-} T A X+\alpha_{13} \ln P_{-} A \& A \ln P_{-} M A S+\alpha_{23} \ln P_{-} T A X \ln P_{-} M A S \\
& +\beta_{12} \ln \text { EDUC } \ln T R A I N+\beta_{13} \ln E D U C \ln E X P E R+\beta_{23} \ln T R A I N \ln E X P E R \\
& +\gamma_{12} \ln \text { PARTNERS In PROFESSIONAL }+\delta_{11} \ln P_{-} A \& A \ln E D U C+\delta_{12} \ln P_{-} A \& A \ln T R A I N \\
& +\delta_{13} \ln P_{-} A \& A \ln \text { EXPER }+\delta_{21} \ln P_{-} T A X \ln E D U C+\delta_{22} \ln P_{-} T A X \ln T R A I N \\
& +\delta_{23} \ln P_{-} T A X \ln \text { EXPER }+\delta_{31} \ln P_{-} M A S \ln E D U C++\delta_{32} \ln P_{-} M A S \ln \text { TRAIN } \\
& +\delta_{33} \ln P_{-} M A S \ln \text { EXPER }+\theta_{11} \ln P_{-} A \& A \ln \text { PARTNERS } \\
& +\theta_{12} \ln \text { P_A\&A } \ln \text { PROFESSIONALS }+\theta_{21} \ln P_{\text {TAX }} \ln \text { PARTNERS } \\
& +\theta_{22} \ln P_{\text {TAX }} \ln \text { PROFESSIONALS }+\theta_{31} \ln P_{\text {MAS }} \ln \text { PARTNERS } \\
& +\theta_{32} \ln P_{M A S} \ln \text { PROFESSIONALS }+\pi_{11} \ln \text { EDUC } \ln \text { PARTNERS } \\
& +\pi_{12} \ln \text { EDUC } \ln \text { PROFESSIONALS }+\pi_{21} \ln \text { TRAIN } \ln \text { PARTNERS } \\
& +\pi_{22} \ln \text { TRAIN } \ln \text { PROFESSIONALS }+\pi_{31} \ln \text { EXPER } \ln \text { PARTNERS } \\
& +\pi_{32} \ln \text { EXPERR In PROFESSIONALS }+\varphi_{1} C P A_{A C T}+\varphi_{2} B I G 4+\varphi_{3} C P A_{A C T} B I G 4
\end{aligned}
$$

Based on the revenue share Equation (3), the translog revenue function in Equation (4), and the proxy variables of the empirical data, the estimated models of the revenue share functions of the public accounting industry in this study can be expressed as follows:

Model 2: $A \mathcal{E} A \%$ function estimation formula:

$$
\begin{aligned}
A \& A \%=\alpha_{1}+ & \alpha_{11} \ln P \_A \& A+\alpha_{12} \ln P \_T A X+\alpha_{13} \ln P \_M A S+\delta_{11} \ln E D U C+\delta_{12} \ln T R A I N \\
& +\delta_{13} \ln X P E R+\theta_{11} \ln \text { PARTNERS }+\theta_{12} \ln \text { PROFESSIONALS }+\varphi_{1} C P A \_A C T+\varphi_{2} \text { BIG4 } \\
& +\varphi_{3} \text { CPA_ACT BIG }
\end{aligned}
$$


Model 3: $T A X \%$ function estimation formula:

$T A X \%=\alpha_{2}+\alpha_{22} \ln P_{-} T A X+\alpha_{12} \ln P_{-} A \& A+\alpha_{23} \ln P_{-} M A S+\delta_{21} \ln E D U C+\delta_{22} \ln$ TRAIN

$+\delta_{23} \ln$ EXPER $+\theta_{21} \ln$ PARTNERS $+\theta_{22} \ln$ PROFESSIONALS $+\varphi_{1}$ CPA_ACT $+\varphi_{2}$ BIG4

$+\varphi_{3} C P A \_A C T$ BIG4

Model 4: MAS\% function estimation formula:

$M A S \%=\alpha_{3}+\alpha_{33} \ln P_{-} M A S+\alpha_{13} \ln P_{-} A \& A+\alpha_{23} \ln P_{-} T A X+\delta_{31} \ln E D U C+\delta_{32} \ln$ TRAIN

$+\delta_{33} \ln$ EXPER $+\theta_{31} \ln$ PARTNERS $+\theta_{32} \ln$ PROFESSIONALS $+\varphi_{1}$ CPA_ACT $+\varphi_{2}$ BIG4

$+\varphi_{3} C P A \_A C T$ BIG4

$A \mathcal{E} A \%, T A X \%$ and $M A S \%$ represent the revenue shares $\left(r_{i} \%\right.$ in (3)) of the three output services.

Based on the translog revenue function in Equation (4), and the proxy variables of the empirical data, the average partial effect (APE) of different variables in this study on REVENUE can be expressed as follows:

The APE of P_A\&A on REVENUE:

$\partial \ln R E \hat{V} E N U E / \partial \ln P \_A \& A$

$=\hat{\alpha}_{1}+\hat{\alpha}_{11} \overline{\ln P \_A \& A}+\hat{\alpha}_{12} \overline{\ln P_{-} T A X}+\hat{\alpha}_{13} \overline{\ln P_{-} M A S}+\hat{\delta}_{11} \overline{\ln E D U C}+\hat{\delta}_{12} \overline{\ln T R A I N}$

$+\hat{\delta}_{13} \overline{\ln E X P E R}+\hat{\theta}_{11} \overline{\ln \text { PARTNERS }}+\hat{\theta}_{12} \overline{\ln \text { PROFESSIONALS }}$

The APE of P_TAX on REVENUE:

$\partial \ln R E \hat{V} E N U E / \partial \ln P_{-} T A X$

$=\hat{\alpha}_{2}+\hat{\alpha}_{22} \overline{\ln P_{-} T A X}+\hat{\alpha}_{12} \overline{\ln P_{-} A \& A}+\hat{\alpha}_{23} \overline{\ln P_{-} M A S}+\hat{\delta}_{21} \overline{\ln E D U C}+\hat{\delta}_{22} \overline{\ln T R A I N}$

$+\hat{\delta}_{23} \overline{\ln E X P E R}+\hat{\theta}_{21} \overline{\ln \text { PARTNERS }}+\hat{\theta}_{22} \overline{\ln \text { PROFESSIONALS }}$

The APE of $P \_M A S$ on REVENUE

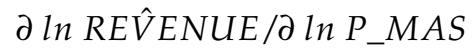

$$
\begin{aligned}
& =\left(1-\hat{\alpha}_{1}-\hat{\alpha}_{2}\right)+\hat{\alpha}_{33} \overline{\ln P_{-} M A S}+\hat{\alpha}_{13} \overline{\ln P_{-} A \& A}+\hat{\alpha}_{23} \overline{\ln P_{-} T A X}+\hat{\delta}_{31} \overline{\ln E D U C} \\
& +\hat{\delta}_{32} \overline{\ln T R A I N}+\hat{\delta}_{33} \overline{\ln E X P E R}+\hat{\theta}_{31} \overline{\ln \text { PARTNERS }}+\hat{\theta}_{32} \overline{\ln \text { PROFESSIONALS }}
\end{aligned}
$$

The APE of EDUC on REVENUE:

$\partial \ln R E \hat{V E N U E / \partial \ln E D U C}$

$=\hat{\beta}_{1}+\hat{\beta}_{11} \overline{\ln E D U C}+\hat{\beta}_{12} \overline{\ln T R A I N}+\hat{\beta}_{13} \overline{\ln E X P E R}+\hat{\delta}_{11} \overline{\ln P_{-} A \& A}+\hat{\delta}_{21} \overline{\ln P_{-} T A X}$

$+\hat{\delta}_{31} \overline{\ln P \_M S A S}+\hat{\pi}_{11} \overline{\ln \text { PARTNERS }}+\hat{\pi}_{12} \overline{\ln \text { PROFESSIONALS }}$

The APE of TRAIN on REVENUE:

$\partial \ln R E \hat{V} E N U E / \partial \ln T R A I N$

$=\hat{\beta}_{2}+\hat{\beta}_{22} \overline{\ln T R A I N}+\hat{\beta}_{12} \overline{\ln E D U C}+\hat{\beta}_{23} \overline{\ln E X P E R}+\hat{\delta}_{12} \overline{\ln P_{-} A \& A}+\hat{\delta}_{22} \overline{\ln P_{-} T A X}$

$+\hat{\delta}_{32} \overline{\ln P \_M S A S}+\hat{\pi}_{21} \overline{\ln \text { PARTNERS }}+\hat{\pi}_{22} \overline{\ln \text { PROFESSIONALS }}$

The APE of EXPER on REVENUE:

$\partial \ln R E \hat{V} E N U E / \partial \ln E X P E R$

$=\hat{\beta}_{3}+\hat{\beta}_{33} \overline{\ln E X P E R}+\hat{\beta}_{13} \overline{\ln E D U C}+\hat{\beta}_{23} \overline{\ln T R A I N}+\hat{\delta}_{13} \overline{\ln P_{-} A \& A}+\hat{\delta}_{23} \overline{\ln P_{-} T A X}$

$+\hat{\delta}_{33} \overline{\ln P \_M S A S}+\hat{\pi}_{31} \overline{\ln \text { PARTNERS }}+\hat{\pi}_{32} \overline{\ln \text { PROFESSIONALS }}$ 
The APE of PARTNERS on REVENUE:

ว $\ln R E \hat{V} E N U E / \partial \ln$ PARTNERS

$$
\begin{aligned}
& =\hat{\gamma}_{1}+\hat{\gamma}_{11} \overline{\ln P A R T N E R S}+\hat{\gamma}_{12} \overline{\ln P R O F E S S I O N A L S}+\hat{\theta}_{11} \overline{\ln P_{-} A \& A}+\hat{\theta}_{21} \overline{\ln P_{-} T A X} \\
& +\hat{\theta}_{31} \overline{\ln P_{-} M A S}+\hat{\pi}_{11} \overline{\ln E D U C}+\hat{\pi}_{21} \overline{\ln T R A I N}+\hat{\pi}_{31} \overline{\ln E X P E R}
\end{aligned}
$$

The APE of PROFESSIONALS on REVENUE:

ว $\ln R E \hat{V} E N U E / \partial \ln$ PROFESSIONALS

$$
\begin{aligned}
& =\hat{\gamma}_{2}+\hat{\gamma}_{22} \overline{\ln \text { PROFESSIONALS }}+\hat{\gamma}_{12} \overline{\ln \text { PARTNERS }}+\hat{\theta}_{12} \overline{\ln P_{-} A \& A}+\hat{\theta}_{22} \overline{\ln P_{-} T A X} \\
& +\hat{\theta}_{33} \overline{\ln P_{-} M A S}+\hat{\pi}_{12} \overline{\ln E D U C}+\hat{\pi}_{22} \overline{\ln T R A I N}+\hat{\pi}_{32} \overline{\ln \text { EXPER }}
\end{aligned}
$$

\section{Results}

\subsection{Descriptive Statistics and Correlation Matrix}

Descriptive statistics of sample data in Table 2 show that the median of all variables related to size was far below the mean, thus indicating that the data was skewed to the right. High standard deviation indicates that there were big differences between Big 4 and non-Big 4 among large accounting firms in Taiwan in terms of size and composition. In terms of human capital, there were small differences between the educational background (EDUC) and years of experience (EXPER) of employees from different large accounting

\begin{tabular}{|c|c|c|c|c|c|}
\hline \multicolumn{6}{|c|}{ 1989-2017 ( $\mathrm{N}=2210)$} \\
\hline Variables & Mean & Std. Dev. & Minimum & Median & Maximum \\
\hline REVENUE & NT\$117.00 & NT\$530.00 & NT\$0.01 & NT\$23.32 & NT\$7510.00 \\
\hline P_AEA & NT\$0.12 & NT\$0.14 & NT\$0.01 & NT\$0.09 & NT\$3.08 \\
\hline$P_{-} T A X$ & NT\$0.09 & NT\$0.20 & NT\$0.01 & NT\$0.07 & NT\$8.00 \\
\hline$P \_M A S$ & NT\$0.04 & $\mathrm{NT} \$ 0.12$ & NT\$0.01 & NT\$0.02 & $\mathrm{NT} \$ 2.96$ \\
\hline EDUC & 15.29 & 0.95 & 4.94 & 15.39 & 20.33 \\
\hline TRAIN & NT\$0.91 & $\mathrm{NT} \$ 4.79$ & $\mathrm{NT} \$ 0.00$ & NT\$0.06 & NT\$59.89 \\
\hline EXPER & 33.78 & 3.72 & 26.46 & 33.00 & 50.83 \\
\hline PARTNERS & 7.09 & 12.67 & 3 & 4 & 160 \\
\hline PROFESSIONALS & 69.58 & 228.79 & 6 & 22 & 3071 \\
\hline$A \mathcal{E} A \%$ & 32.73 & 15.36 & 0.21 & 30.76 & 94.00 \\
\hline$T A X \%$ & 49.22 & 17.72 & 0.34 & 49.86 & 98.01 \\
\hline$M A S \%$ & 18.07 & 14.73 & 0.02 & 12.99 & 82.80 \\
\hline
\end{tabular}
firms. Meanwhile, the investment of large accounting firms in training (TRAIN) generally accounted for a low proportion of total revenue (REVENUE).

Table 2. Descriptive statistics.

The variable REVENUE, AEA, TAX, MAS and TRAIN units in this table are NT\$ million.

Descriptive statistics of accounting service revenue show that from the years of 1989 to 2017, A\&A was the highest average price business among large accounting firms, followed by TAX and MAS respectively. TAX generated $49.22 \%$ of the total revenue, the highest revenue share among large accounting firms. Meanwhile, $A \mathcal{E} A \%$ and $M A S \%$ were $32.73 \%$ and $18.07 \%$, respectively.

Pearson and Spearman correlations between average service mix, the big four and the amendment of Certified Public Accountant Act variables over the 29 years are presented in Table $3 . A \mathcal{E} A \%, T A X \%$ and $M A S \%$ were significantly negatively correlated, as they were respectively referred to as part of the net revenue. $A \mathcal{E} A \%$ had a significant positive correlation with the Big 4 , the correlation coefficient between $T A X \%$ and Big 4 was significantly negative, and the correlation coefficient between $M A S \%$ and the Big 4 was significantly positive in Spearman correlation. This suggests that the Big 4 relies less on tax services and more on accounting, auditing and management advisory services to generate revenue. 
Table 3. Spearman/Pearson correlation coefficient table ( $p$-values in parentheses).

\begin{tabular}{cccccc}
\hline & A\&A \% & TAX\% & MAS\% & BIG4 & CPA_ACT \\
\hline A\&A\% & 1.000 & $-\mathbf{0 . 5 6 7}$ & $-\mathbf{0 . 1 7 0}$ & $\mathbf{0 . 2 8 6}$ & $\mathbf{- 0 . 0 5 4}$ \\
& & $(0.000)$ & $(0.000)$ & $(0.000)$ & $(0.012)$ \\
TAX\% & $\mathbf{- 0 . 6 2 1}$ & 1.000 & $-\mathbf{0 . 6 0 1}$ & $-\mathbf{0 . 2 6 8}$ & -0.011 \\
& $(0.000)$ & & $(0.000)$ & $(0.000)$ & $(0.598)$ \\
MAS\% & $\mathbf{- 0 . 2 8 1}$ & $\mathbf{- 0 . 5 7 0}$ & 1.000 & $\mathbf{0 . 0 4 2}$ & 0.034 \\
& $(0.000)$ & $(0.000)$ & & $(0.050)$ & $(0.114)$ \\
BIG4 & $\mathbf{0 . 3 1 4}$ & $\mathbf{- 0 . 2 5 5}$ & -0.016 & 1.000 & -0.026 \\
& $(0.000)$ & $(0.000)$ & $(0.458)$ & & $(0.219)$ \\
CPA_ACT & $\mathbf{- 0 . 5 3 0}$ & -0.012 & $\mathbf{0 . 0 7 0}$ & -0.026 & 1.000 \\
& $(0.013)$ & $(0.566)$ & $(0.001)$ & $(0.219)$ &
\end{tabular}

Note: 1. Bold values denote statistical significance at the $p<0.05$ level; 2 . Table 3 reports correlations between main variables. The upper triangle is the Spearman correlation coefficient, and the lower triangle is the Pearson correlation coefficient.

At the same time, $C P A \_A C T$ was significantly negatively correlated with $A \mathcal{E} A \%$, $C P A \_A C T$ was negatively correlated with $T A X \%$ (but not significantly), $C P A \_A C T$ and $M A S \%$ were positively correlated (but not significantly) in the Spearman correlation. In addition, CPA_ACT and MAS\% were significantly positively correlated in Pearson correlation. Based on this, we assume that before the implementation of the new Certified Public Accountant Act, large accounting firms had higher $A \mathcal{E} A \%$ and lower $M A S \%$. In contrast, after the implementation of the new Certified Public Accountant Act, $A \mathcal{E} A \%$ decreased and $M A S \%$ increased.

4.2. The Impact of the Amendment of the Certified Public Accountant Act on the Revenue of Large Accounting Firms and Each Revenue Share

This study mainly analyzes the impact of Taiwan's new Certified Public Accountant Act on the revenue, $A \mathcal{E} A \%, T A X \%$, and $M A S \%$ of large accounting firms. Taking 2008 when the new Certified Public Accountant Act took effect as the boundary, through the Chow Test to analyze the revenue, $A \mathcal{E} A \%, T A X \%$, and $M A S \%$ of large accounting firms, the $\mathrm{F}$ statistics were $8.69,8.59,3.56$ and 2.54 , respectively. The rejection of the null hypothesis at a significant level of $10 \%$ indicates that the new Certified Public Accountant Act would have an impact on revenue, $A \mathcal{E} A \%, T A X \%$, and $M A S \%$. Therefore, this study puts $C A P \_A C T$ as a dummy variable into the model to further analyze its influence on each function.

4.3. Paired Sample t-Test of Average Revenue Share before and after the Implementation of the New Certified Public Accountant Act

Table 4 shows the $t$-test results of the paired samples of the averages of $A \mathcal{E} A \%, T A X \%$, and $M A S \%$ before and after the implementation of the new Certified Public Accountant Act with 2008 as the cut-off point. As shown in Table 4, the average $A \mathcal{E} A \%$ of Taiwan's large accounting firms from 1989 to 2007 was $35.36 \%$, while this value dropped to $30.32 \%$ from 2008 to 2017, and the difference is statistically significant. At the same time, Table 4 also shows that the average MAS\% of Taiwan's large accounting firms had increased from $15.81 \%$ in $1989-2007$ to $20.28 \%$ in $2008-2017$, and the difference is statistically significant. This shows that after the implementation of the new Certified Public Accountant Act, accounting firms generally reduced the proportion of $A \mathcal{E} A$ cases and increased the proportion of $M A S$ cases. This result is consistent with our research hypothesis. Table 4 also shows that $T A X \%$ increased slightly after the implementation of the new Certified Public Accountant Act, but this result is not statistically significant. 
Table 4. Paired sample $t$-test of average revenue share.

\begin{tabular}{ccccc}
\hline Variables & Year & Mean & Difference & $p$-Value \\
\hline \multirow{2}{*}{$A \mathcal{E} A \%$} & $1989-2007$ & $\mathbf{3 5 . 3 6}$ & $\mathbf{- 5 . 0 4}$ & 0.000 \\
& $2008-2017$ & $\mathbf{3 0 . 3 2}$ & & \\
\multirow{2}{*}{$T A X \%$} & $1989-2007$ & 48.83 & 0.57 & 0.650 \\
& $2008-2017$ & 49.40 & & 0.000 \\
\hline
\end{tabular}

Note: 2. Bold values denote statistical significance at the $p<0.05$ level.

\subsection{Estimation Results of Revenue Function and Revenue Share Function of Large Accounting Firms}

\subsubsection{The Revenue Function}

In Table 5, we present the parameter estimates and test results for the revenue function. We adopted a more flexible translog format instead of the simpler Cobb-Douglas (loglinear) format. In order to evaluate whether the translog form could provide an appropriate representation of the revenue function, we tested whether the following conditions in (4) are met:

$$
\alpha_{i l}=\beta_{j m}=\gamma_{k n}=\delta_{i j}=\theta_{i k}=\pi_{j k}=0 \text { for all } i, l, j, m=1,2,3 ; k, n=1,2 .
$$

Table 5. Estimation of translog revenue function of large accounting firms over 1989-2017.

\begin{tabular}{|c|c|c|c|c|c|}
\hline Variables & Estimate & Prob & Variables & Estimate & Prob \\
\hline Intercept & -217.93 & 0.000 & (lnPARTNERS)2 & 0.08 & 0.426 \\
\hline lnP_A\&A & 0.98 & 0.703 & (lnPROFESSIONAL)2 & 0.03 & 0.232 \\
\hline $\operatorname{lnP} \_\mathrm{TAX}$ & 2.72 & 0.371 & $\left(\operatorname{lnP} \_\mathrm{A} \& \mathrm{~A}\right)\left(\ln \mathrm{P}_{-} \mathrm{TAX}\right)$ & -0.02 & 0.696 \\
\hline lnP_MAS & -2.70 & 0.741 & $\left(\operatorname{lnP} \_A \& A\right)\left(\operatorname{lnP} \_M A S\right)$ & -0.02 & 0.767 \\
\hline $\operatorname{lnEDUC}$ & 63.64 & 0.000 & $\left(\operatorname{lnP} P_{-} \mathrm{TAX}\right)\left(\ln \mathrm{P}_{-} \mathrm{MAS}\right)$ & 0.01 & 0.887 \\
\hline $\operatorname{lnTRAIN}$ & 0.72 & 0.050 & $(\operatorname{lnEDUC})(\operatorname{lnTRAIN})$ & -0.29 & 0.011 \\
\hline $\operatorname{lnEXPER}$ & 71.45 & 0.000 & $(\operatorname{lnEDUC})(\operatorname{lnEXPER})$ & -16.88 & 0.000 \\
\hline lnPARTNERS & 9.05 & 0.039 & $(\operatorname{lnTRAIN})(\operatorname{lnEXPER})$ & 0.08 & 0.086 \\
\hline lnPROFESSIONAL & -1.97 & 0.271 & (lnPARTNERS)(lnPROFESSIONAL) & -0.21 & 0.011 \\
\hline$\left(\ln P \_A \& A\right) 2$ & -0.03 & 0.299 & $\left(\operatorname{lnP} \_A \& A\right)(\operatorname{lnEDUC})$ & 0.02 & 0.980 \\
\hline$\left(\operatorname{lnP} P_{-} \mathrm{TAX}\right) 2$ & 0.00 & 0.905 & $\left(\ln P \_A \& A\right)(\operatorname{lnTRAIN})$ & -0.01 & 0.504 \\
\hline (lnP_MAS)2 & 0.00 & 0.808 & $\left(\ln P \_A \& A\right)(\ln E X P E R)$ & 0.00 & 0.991 \\
\hline$(\operatorname{lnEDUC}) 2$ & -0.80 & 0.102 & $\left(\ln \bar{P}_{-} \mathrm{TAX}\right)(\operatorname{lnEDUC})$ & -0.14 & 0.895 \\
\hline$(\operatorname{lnTRAIN}) 2$ & 0.01 & 0.000 & $\left(\ln P_{-} \mathrm{TAX}\right)(\operatorname{lnTRAIN})$ & -0.02 & 0.114 \\
\hline$(\operatorname{lnEXPER}) 2$ & -3.48 & 0.019 & $\left(\operatorname{lnP} \_\mathrm{TAX}\right)(\operatorname{lnEXPER})$ & -0.39 & 0.473 \\
\hline$\left(\operatorname{lnP} \_\mathrm{MAS}\right)(\operatorname{lnEDUC})$ & 0.52 & 0.416 & (lnEDŪC)(lnPARTNERS) & -2.12 & 0.084 \\
\hline$\left(\operatorname{lnP}{ }_{-} \mathrm{MAS}\right)(\operatorname{lnTRAIN})$ & 0.00 & 0.523 & (lnEDUC)(lnPROFESSIONAL) & 1.76 & 0.000 \\
\hline (lnP_MAS)(lnEXPER) & 0.44 & 0.104 & $(\operatorname{lnTRAIN})(\operatorname{lnPARTNERS})$ & 0.01 & 0.609 \\
\hline (lnP_A\&A)(lnPARTNERS) & 0.11 & 0.323 & $(\operatorname{lnTRAIN})(\operatorname{lnPROFESSIONAL)}$ & 0.00 & 0.560 \\
\hline (lnP_A\&A)(lnPROFESSIONAL) & 0.00 & 0.979 & $(\operatorname{lnEXPER})(\operatorname{lnPARTNERS})$ & -0.08 & 0.910 \\
\hline$\left(\operatorname{lnP} \_\mathrm{TAX}\right)(\ln P A R T N E R S)$ & -0.22 & 0.096 & $(\operatorname{lnEXPER})(\operatorname{lnPROFESSIONAL})$ & -0.69 & 0.015 \\
\hline$\left(\operatorname{lnP} P_{-} \mathrm{TAX}\right)(\operatorname{lnPROFESSIONAL})$ & -0.03 & 0.646 & CPA_ACT & 0.50 & 0.000 \\
\hline (lnP_MAS)(lnPARTNERS) & -0.05 & 0.474 & BIG4 & 0.14 & 0.540 \\
\hline$\left(\ln P \_M A S\right)(\operatorname{lnPROFESSIONAL)}$ & 0.04 & 0.300 & CPA_ACTBIG4 & 0.32 & 0.320 \\
\hline Adjusted R-squared & & & 0.63 & & \\
\hline System degrees of freedom & & & 2210 & & \\
\hline \multicolumn{6}{|c|}{ Test of $\log$-linear specification $\left(\mathrm{H} 0: \alpha_{i l}=\beta_{j m}=\gamma_{k n}=\delta_{i j}=\theta_{i k}=\pi_{j k}=0\right.$ for all $i, l, j, m=1,2,3 ; k, n=1,2$.): } \\
\hline F-statistic & & & 9.70 & & \\
\hline Significance level & & & 0.000 & & \\
\hline
\end{tabular}

Note: 3. Bold values denote statistical significance at the $p<0.05$ level.

The detected F statistical value was 9.70, as listed in Table 5, which significantly rejected the null hypothesis of log-linear specification. In other words, this suggests that the translog model is more suitable for analyzing the revenue function of accounting firms than the Cobb-Douglas model. 


\subsubsection{Total Revenue}

Column (I) of Table 6 shows the APE of different variables in this study on REVENUE. It can be seen from Table 6 that the APE of CAP_ACT to the total revenue of large accounting firms was positive and significant. At the same time, Table 5 shows that the estimated value of the $C A P \_A C T$ coefficient was significantly positive in the revenue function equation. These results showed that the new Certified Public Accountant Act increased the revenue of large accounting firms. We believe this might have been mainly due to the positive impact of the new Certified Public Accountant Act on the revenue of accounting firms by relaxation of the scope of accountants' practice. Furthermore, from Table 6, it can be seen that the APE of CAP_ACT on Big 4 revenue was 0.82 and significant, which is greater than 0.50 for non-Big 4, thereby, indicating that the impact of the new Certified Public Accountant Act on accounting firms' will increase revenue to a greater extent for Big 4 . This is because Big 4 was occupying most of the market share, and Big 4 commanded more than proportionate revenue from their services relative to the other accounting firms. This verified Hypothesis 1.

Table 6. Average partial effect (APE) between variables.

\begin{tabular}{|c|c|c|c|c|c|c|c|c|}
\hline \multirow{2}{*}{ APE } & \multicolumn{2}{|c|}{ (I) REVENUE } & \multicolumn{2}{|c|}{ (II) $\mathrm{A} \& \mathrm{~A} \% / 100$} & \multicolumn{2}{|c|}{ (III) TAX\%/100 } & \multicolumn{2}{|c|}{ (IV) MAS $\% / 100$} \\
\hline & Mean & F-Value & Mean & $F$-Value & Mean & F-Value & Mean & $F$-Value \\
\hline$P \_A A A$ & 0.48 & 1.97 & 13.94 & 713.43 & -10.19 & 249.82 & -3.72 & 45.34 \\
\hline$P_{-}^{-} T A X$ & 0.22 & 4.38 & -4.56 & 58.07 & 6.46 & 76.43 & -2.14 & 11.43 \\
\hline P_MAS & -30.56 & 2.39 & -2.56 & 54.73 & -6.60 & 237.54 & 9.23 & 632.05 \\
\hline EDUC & 0.70 & 34.20 & 13.11 & 16.05 & -7.66 & 3.59 & -5.48 & 2.50 \\
\hline TRAIN & 0.00 & 6.41 & -0.08 & 1.76 & 0.07 & 0.84 & 0.02 & 0.05 \\
\hline EXPER & -8.16 & 4.43 & 3.30 & 1.33 & 10.12 & 8.17 & -13.36 & 19.35 \\
\hline PARTNERS & 1.13 & 37.34 & 4.98 & 39.57 & 1.86 & 3.60 & -6.94 & 68.39 \\
\hline PROFESSIONAL & 0.17 & 6.93 & 0.68 & 4.08 & -0.26 & 0.39 & -0.50 & 1.96 \\
\hline \multicolumn{9}{|l|}{ BIG4: } \\
\hline When CPA_ACT $=0$ & 0.14 & \multirow{2}{*}{0.80} & 3.25 & \multirow{2}{*}{1.45} & -10.44 & \multirow{2}{*}{8.75} & 7.59 & \multirow{2}{*}{6.45} \\
\hline When $C P A \_A C T=1$ & 0.47 & & 3.87 & & -6.07 & & 2.72 & \\
\hline \multicolumn{9}{|l|}{ CPA_ACT: } \\
\hline When $B I G 4=0$ & 0.50 & \multirow{2}{*}{34.52} & -1.41 & \multirow{2}{*}{1.68} & -0.53 & \multirow{2}{*}{0.61} & 1.84 & \multirow{2}{*}{2.99} \\
\hline When $B I G 4=1$ & 0.82 & & -0.80 & & 3.84 & & -3.03 & \\
\hline
\end{tabular}

Note: 4. Bold values denote statistical significance at the $p<0.05$ level.

\subsubsection{Revenue Shares}

In columns (II), (III) and (IV) of Table 6, we obtained the APE of CPA_ACT for $A \mathcal{E} A \%$, $T A X \%$ and $M A S \%$ of large accounting firms. (When we delete the dummy variable Big 4 in Model 1-4, the results represented by the coefficient estimate and APE of CPA_ACT are very similar to those reported in Tables 5-9, we do not present these results here.)

In column (II) of Table 6, the APE of CAP_ACT was negative and significant for accounting firms $A \mathcal{E} A \%$, while in Table 7, the estimated value of $C A P \_A C T$ coefficient was significantly negative in the $A \mathcal{E} A$ revenue share equation. This shows that the new Certified Public Accountant Act reduced the $A \mathcal{E} A \%$ of accounting firms. The possible reason is that the new Certified Public Accountant Act strengthened the supervision of $A \& A$ by the regulatory authorities, thus making accounting firms more cautious in providing $A \mathcal{E} A$. In addition, we found that the APE of CAP_ACT for the Big 4's $A \mathcal{E} A \%$ is -0.80 , which was greater than-1.41 of non-Big 4 . This shows that the implementation of the new Certified Public Accountant Act had a greater impact on the reduction of non-Big 4's $A \mathcal{E} A \%$ than Big 4's $A \mathcal{E} A \%$. For a long time, the Big 4 had rich experience in $A \mathcal{E} A$, good standardization, and a strong ability to put pressure on supervision. Therefore, the new Certified Public Accountant Act had a relatively limited effect on the reduction of Big 4's $A \mathcal{E} A \%$. All of the above verified Hypothesis 2 of this study. 
Table 7. Estimation of $A \mathcal{E} A \%$ function of large accounting firms over 1989-2017.

\begin{tabular}{|c|c|c|}
\hline (II) $\mathrm{A} \& \mathrm{~A} \% / 100$ & \multirow{2}{*}{ Estimate } & \multirow{2}{*}{ Prob } \\
\hline Variables & & \\
\hline lnP_A\&A & -107.30 & 0.000 \\
\hline$\left(\ln P \_A \& A\right) 2$ & 13.94 & 0.000 \\
\hline$\left(\operatorname{lnP} \_A \& A\right)\left(\ln P \_T A X\right)$ & -4.56 & 0.000 \\
\hline (lnP_A\&A)(lnP_MAS) & -2.56 & 0.000 \\
\hline$\left(\ln P \_A \& A\right)(\ln E D U C)$ & 13.11 & 0.000 \\
\hline$\left(\ln P \_A \& A\right)(\operatorname{lnTRAIN})$ & -0.08 & 0.185 \\
\hline (lnP_A\&A)(lnEXPER) & 3.30 & 0.250 \\
\hline (lnP_A\&A)(lnPARTNERS) & 4.98 & 0.000 \\
\hline$\left(\operatorname{lnP} \_\mathrm{A} \& \mathrm{~A}\right)(\ln \mathrm{PROFESSIONAL})$ & 0.68 & 0.043 \\
\hline CPA_ACT & -1.41 & 0.068 \\
\hline BIG4 & 3.25 & 0.108 \\
\hline CPA_ACTBIG4 & 0.62 & 0.856 \\
\hline Adjusted R-squared & \multicolumn{2}{|c|}{0.63} \\
\hline System degrees of freedom & \multicolumn{2}{|c|}{2210} \\
\hline \multicolumn{3}{|c|}{$\begin{array}{l}\text { Test of log-linear specification ( } \mathrm{H} 0 \text { : } \\
\left.\delta_{i j}=\theta_{i k}=\pi_{j k}=0 \text { for all } i, l, j, m=1,2,3 ; k, n=1,2 .\right) \text { : }\end{array}$} \\
\hline F-statistic & \multicolumn{2}{|c|}{9.70} \\
\hline Significance level & \multicolumn{2}{|c|}{0.000} \\
\hline
\end{tabular}

Note: 5. Bold values denote statistical significance at the $p<0.05$ level.

Table 8. Estimation of TAX\% function of large accounting firms over 1989-2017.

\begin{tabular}{|c|c|c|}
\hline (III) TAX\%/100 & \multirow{2}{*}{ Estimate } & \multirow{2}{*}{ Prob } \\
\hline Variables & & \\
\hline lnP_TAX & 140.98 & 0.000 \\
\hline$\left(\ln P_{-} \mathrm{TAX}\right)^{2}$ & 6.46 & 0.000 \\
\hline$\left(\ln P \_A \& A\right)\left(\ln P \_T A X\right)$ & -10.19 & 0.000 \\
\hline (lnP_TAX)(lnP_MAS) & -6.60 & 0.000 \\
\hline$\left(\operatorname{lnP} \_\mathrm{TAX}\right)(\operatorname{lnEDUC})$ & -7.66 & 0.058 \\
\hline$\left(\operatorname{lnP}{ }_{-} \mathrm{TAX}\right)(\operatorname{lnTRAIN})$ & 0.07 & 0.360 \\
\hline$\left(\operatorname{lnP} P_{-} \mathrm{TAX}\right)(\operatorname{lnEXPER})$ & 10.12 & 0.004 \\
\hline$(\operatorname{lnP}$ TAX)(lnPARTNERS) & 1.86 & 0.058 \\
\hline$\left(\operatorname{lnP} \_\mathrm{TAX}\right)(\operatorname{lnPROFESSIONAL})$ & -0.26 & 0.535 \\
\hline CPA_ACT & -0.53 & 0.578 \\
\hline BIG4 & -10.44 & 0.000 \\
\hline CPA_ACTBIG4 & 4.37 & 0.298 \\
\hline Adjusted R-squared & \multicolumn{2}{|c|}{0.63} \\
\hline System degrees of freedom & \multicolumn{2}{|c|}{2210} \\
\hline \multicolumn{3}{|c|}{$\begin{array}{l}\text { Test of log-linear specification (H0: } \\
\left.\delta_{i j}=\theta_{i k}=\pi_{j k}=0 \text { for all } i, l, j, m=1,2,3 ; k, n=1,2 .\right) \text { : }\end{array}$} \\
\hline F-statistic & \multicolumn{2}{|c|}{9.70} \\
\hline Significance level & \multicolumn{2}{|c|}{0.000} \\
\hline
\end{tabular}

Note: 6. Bold values denote statistical significance at the $p<0.05$ level. 
Table 9. Estimation of MAS\% function of large accounting firms over 1989-2017.

\begin{tabular}{|c|c|c|}
\hline (IV) MAS $\% / 100$ & \multirow{2}{*}{ Estimate } & \multirow{2}{*}{ Prob } \\
\hline Variables & & \\
\hline lnP_MAS & 68.21 & 0.000 \\
\hline$\left(\operatorname{lnP} \_\mathrm{MAS}\right)^{2}$ & 9.23 & 0.000 \\
\hline (lnP_A\&A)(lnP_MAS) & -3.72 & 0.000 \\
\hline$\left(\operatorname{lnP} \_\mathrm{TAX}\right)\left(\ln \mathrm{P} \_\mathrm{MAS}\right)$ & -2.14 & 0.001 \\
\hline$\left(\operatorname{lnP} \_M A S\right)(\operatorname{lnEDUC})$ & -5.48 & 0.114 \\
\hline (lnP_MAS)(lnTRAIN) & 0.02 & 0.817 \\
\hline (lnP_MAS)(lnEXPER) & -13.36 & 0.000 \\
\hline (lnP_MAS)(lnPARTNERS) & -6.94 & 0.000 \\
\hline (lnP_MAS)(lnPROFESSIONAL) & -0.50 & 0.162 \\
\hline CPA_ACT & 1.84 & 0.025 \\
\hline BIG4 & 7.59 & 0.000 \\
\hline CPA_ACTBIG4 & -4.87 & 0.177 \\
\hline Adjusted R-squared & \multicolumn{2}{|c|}{0.63} \\
\hline System degrees of freedom & \multicolumn{2}{|c|}{2210} \\
\hline \multicolumn{3}{|c|}{$\begin{array}{l}\text { Test of log-linear specification }(\mathrm{H} 0 \text { : } \\
\left.\delta_{i j}=\theta_{i k}=\pi_{j k}=0 \text { for all } i, l, j, m=1,2,3 ; k, n=1,2 .\right) \text { : }\end{array}$} \\
\hline F-statistic & \multicolumn{2}{|c|}{9.70} \\
\hline Significance level & \multicolumn{2}{|c|}{0.000} \\
\hline
\end{tabular}

In Table 8, the estimated value of the CAP_ACT coefficient was negative in the TAX revenue share equation, which means that $C A P_{-} A C T$ reduced the $T A X \%$ of accounting firms. The new Certified Public Accountant Act stipulates that accountants can act as agents of tax administrative litigation. Since acting as agents of tax cases can obtain more revenue, accounting firms generally tend to allow more tax experts to act as agents of tax cases, thus reducing the proportion of TAX cases accepted. In addition, the empirical results also showed that the APE of CAP_ACT to the Big 4's TAX\% was 3.84, which is inconsistent with our hypothesis, and since the above statistical results were not significant, hypothesis 3 could not be verified.

As can be seen from Table 6, the APE of CAP_ACT to $M A S \%$ of the non-Big 4 is 1.84, and the APE of CAP_ACT to MAS\% of the Big 4 is -3.03 and significant, and in Table 9, the estimated coefficient value of $C A P_{-} A C T$ was significantly positive in the $M A S$ revenue share equation. Meanwhile, in Table 4 , the $M A S \%$ rose from $15.81 \%$ to $20.28 \%$ after the implementation of the new Certified Public Accountant Act. These results indicate that the implementation of the new Certified Public Accountant Act increased the overall MAS\% of accounting firms, but for the Big 4, the $M A S \%$ would decrease. After the implementation of the new Certified Public Accountant Act, the demand for the management advisory market in Taiwan gradually expanded. In order to meet the huge market demand for management advisory services, and to obtain more revenue in the high-value-added management advisory market, accounting firms generally increased the proportion of MAS cases. At the same time, the Big 4 successively set up management advisory companies to engage in management advisory business, thus stripping out most of the original MAS. Therefore, the new Certified Public Accountant Act would lead to the decrease of $M A S \%$ of the Big 4 . All of the above verified hypothesis 4 proposed in this study.

\section{Additional Analyses}

In addition to testing the APE of CAP_ACT on the revenue and revenue share of accounting firms, this section also provides additional analysis to investigate the impact of $A \mathcal{E} A, T A X, M A S$ price, human resources, and the Big 4 on the total revenue and revenue share. 


\subsection{Big 4}

Table 6 indicates that, the APE of the Big 4 to TAX\% was negative and significant. However, after the implementation of the new Certified Public Accountant Act, its APE for $T A X \%$ rose from -10.44 to -6.07 . This suggest that the Big 4 rely less on $T A X$ to generate revenue, but it is worth noting that the Big 4 have increased their dependence on TAX to further generate revenue after the implementation of the amendment of Certified Public Accountant Act. At the same time, Table 6 also depicts that the Big 4's APE to $M A S \%$ was positive and significant. After the implementation of the new Certified Public Accountant Act, their APE to $M A S \%$ dropped from 7.59 to 2.72 . This indicates that when compared with $T A X$, the Big 4 generated more revenue with MAS, which is considered consistent with the previous research results [65]. Still, the Big 4 reduced their dependence on MAS after the implementation of the amendment of Certified Public Accountant Act. This is consistent with the interpretation that the coefficient estimates of the Big 4 in the $T A X \%$ equation and the $M A S \%$ equation in Tables 8 and 9 were significantly negative and significantly positive, respectively.

We believe that the possible reason for this might have been due to the brand effect. That is because the Big 4 had a positive effect on $M A S \%$. However, after the amendment, the Big 4 set up management advisory companies to divest most MAS, so the positive effect was reduced to a lesser extent after the implementation of the amendment of the Certified Public Accountant Act.

Table 6 also shows that the Big 4 relied more on accounting and auditing to generate revenue both before and after the new Certified Public Accountant Act, but the results were not significant.

\subsection{Prices of Accounting and Auditing (A\&A), Tax Services (TAX) and Management Advisory Services (MAS)}

As can be seen from Table 6, APE of $A \mathcal{E} A$ price to REVENUE and $A \mathcal{E} A \%$ was positive and statistically significant. This indicates that the price increase of $A \mathcal{E} A$ would lead to the increase of $A \mathcal{E} A$ revenue share and total revenue. The APE of TAX price to REVENUE and $T A X \%$ was positive and statistically significant. This indicates that the increase of $T A X$ price would result in the increase of TAX revenue share and total revenue.

However, according to the results given in Table 6, the increase of MAS price would lead to the decrease of total revenue. Through further analysis, we found that although the increase of $M A S$ price could increase $M A S \%$, it also reduced $A \mathcal{E} A \%$ and $T A X \%$. However, as shown in Table 2, the average price of $A \mathcal{E} A$ and TAX was much higher than that of $M A S$, so the increase of $M A S$ price reduced the total revenue of accounting firms.

Here, our advice to the competent authorities of the public accounting industry and accounting firms is that firms should not easily raise the MAS price. Considering the historical trend, we found that it is not conducive to the long-term development of accounting firms. At the same time, accounting firms could raise the price of $A \mathcal{E} A$ and TAX appropriately, so as to increase the total revenue of firms.

\subsection{Human Resources}

Yang, Tsai, and Fu [59] indicated that accounting firms provide services with human resources as the core. Table 6 shows that in terms of the quality of human resources, $E D U C^{\prime}$ 's APE for REVENUE and $A \mathcal{E} A \%$ are positive and significant. This indicates that the investment of large accounting firms on employees with high education backgrounds had a positive effect on the total revenue. However, we found that the APE of TRAIN to REVENUE was 0 , which means that firms' investment in employee training did not promote firms. This partly explains why accounting firms generally only maintained a low proportion of profits to invest in employee training. In addition, we also found, as can be seen from Table 6, that EXPER's APE for REVENUE is negative and significant, indicating that firms' absorption of highly experienced employees will reduce firms' overall revenue, which is inconsistent with theory. 
Furthermore, after the analyses of the above results, we believe that the main reason for this might have been the fact that a person's learning ability has a great relationship with innateness. Education level can directly reflect a person's learning ability. These factors of educational background and ability directly influence occupational attainment [1], and employees with strong learning abilities tend to have stronger work abilities and work efficiency, which can effectively increase the total revenue of accounting firms. However, the training status and experience of employees are acquired, and investing more training costs for employees does not mean that the training objectives would be achieved. At the same time, firms invest large sums of money to absorb employees with rich experience, and yet it is difficult to guarantee that employees' years of employment are directly proportional to their work capabilities. Therefore, the investment in TRAIN and EXPER would be less cost-effective.

In terms of the quantity of human resources, whether it is PARTNERS or PROFESSIONALS, the increase in the number of employees will increase the total revenue of firms, which is consistent with previous research results [81].

\section{Conclusions and Discussion}

We used the translog revenue function and revenue share functions to estimate the impact of Taiwan's amendment of Certified Public Accountant Act in 2007 on large accounting firms, and discussed the relationship between independent variables such as accounting and auditing $(A \mathcal{E} A)$ price, tax services $(T A X)$ price, management advisory services $(M A S)$ price, human resources, the big four accounting firms (Big 4) and a dependent variable of the total revenue (REVENUE) through the average partial effect (APE). This study used an annual pooling data of large accounting firms from the year of 1989 to the year of 2007. This was to undertake an empirical analysis of accounting firms.

The empirical results show that the implementation of the amended Certified Public Accountant Act had a positive effect on the revenue of large accounting firms, and this positive effect was greater for the Big 4, i.e., legal changes enhanced the sustainability of accounting firms' revenue. Meanwhile, the amendment of Certified Public Accountant Act reduced the overall Accounting and Auditing shares $(A \& A \%)$ of large accounting firms, especially with the Big 4 . The amendment of the Certified Public Accountant Act increased the overall management advisory services shares $(M A S \%)$ of large accounting firms, but the $M A S \%$ of the Big 4 decreased.

Additional analyses indicate that the Big 4 relied less on tax services and more on management advisory services, accounting, and auditing to generate revenue. In addition, the increase in the prices of $A \mathcal{E} A$ and $T A X$ would lead to an increase in the total revenue of accounting firms, and the increase in the price of MAS would result in a decrease in the total revenue. Revenue is equal to the price multiplied by the quantity. The key to the relationship between revenue and price lies in the size of the elasticity. If it is elastic, raising the price will lead to a decrease in revenue. As shown in Table 6, the average MAS price $\left(P \_M A S\right)$ obtained in this study is elastic. Therefore, we suggest that it is necessary for accounting policymakers to supervise those accounting firms not to increase the MAS price easily, so as further to enable the firms to benefit from long-term developments. Specifically, regulators can try to set a maximum increase limit on the $P_{-} M A S$ of accounting firms, and convey to partners the important information that the increase of $P \_M A S$ is elastic.

Our analysis of APE also showed that in terms of human resources, the investment of accounting firms in the number of employees is positively related to the total revenue, which might result from larger firms with greater revenue needing more employees. At the same time, firms would increase their total revenue by hiring more highly-educated employees. In addition, according to the additional analyses, we suggest that management should take into account the investment of human resources. To be specific, firms should hire more employees to promote improved operations, and it is necessary to recruit more employees with high educational backgrounds in the process of recruiting employees to improve the overall quality of the firm's human resources. We also suggest that when 
an accounting firm has insufficient funds, if the firm urgently needs to invest in human resources at this time, then it should be more inclined to recruit employees with highly educated backgrounds rather than just prefer employees with more experience. We also discourage excessive investment in employee training, especially when an accounting firm has insufficient funds. It is also important to note that, regulators, clients, creditors and other stakeholders should have a clearer understanding of the increase in the revenue of accounting firms after the amendment of the Certified Public Accountant Act. The amendment of the Act has a great promotional effect on the improvement of the revenue of accounting firms, that is, after the amendment of the Certified Public Accountant Act, the revenue of accounting firms generally improved. Therefore, in this circumstance, stakeholders such as regulators, clients, creditors, etc., should pay special attention to a small part of accounting firms whose revenue may decline, and these firms are likely to have a major adverse situation in their operating conditions. What needs to be noted by stakeholders is that accounting firms with poor operation have greater incentives to lose audit independence in order to obtain revenue. Therefore, the regulators should strengthen the supervision of audit independence of accounting firms with reduced revenue under the background of the amendment of accounting law, and the clients should pay attention to the reputation risk and litigation risk that may be caused by entrusting their business to this type of accounting firm for audits (e.g., the major negative impact of the collapse of Andersen on their clients). In addition, it is necessary for the creditors to add necessary insurance clauses in their contracts.

The public accounting industry is closely related to the development of enterprises and to the economy, and revenue directly affects the survival and development of accounting firms. As far as we know, there are only two research studies in the literature that have discussed the impact of the amendment of accounting laws in the past, and there is no literature discussing the impact of the amendment of the Certified Public Accountant Act on the revenue of accounting firms; therefore, this study fills the gap in the research. We apply translog revenue function and revenue share functions to the impact of the amendment of accounting law on the public accounting industry, and point out the effect of the amendment of Taiwan's Certified Public Accountant Act on the revenue and revenue share of large accounting firms. Our research results will give accounting firms, accounting policymakers, and other stakeholders more to consider concerning the amendment of the Act. At the policy formulation level in particular, the policy formulation department of the public accounting industry can use our research results as a reference for further improvement of the Act.

In the future, researchers may be able to obtain more information about the training and employee experience inputs of accounting firms, so that they can more accurately analyze the impact of those inputs. Another limitation of this study is that we were unable to obtain the accurate results of the Certified Public Accountant Act on the TAX of large accounting firms. This will be another area for future research.

Author Contributions: C.-C.Y. proposed the idea, finished the original and final draft of this paper and gave significant suggestions to the implications of the results. J.C. and W.-C.Y. collected data, established the model, completed the empirical tests and analyzed the results. All authors have read and agreed to the published version of the manuscript.

Funding: This research received no external funding.

Conflicts of Interest: The authors declare no conflict of interest.

\section{References}

1. Walton, P.; Haller, A.; Raffourner, B. International Accounting; International Thomson Publishing Company: London, UK, 1998.

2. Elitaş, C.; Üç, M. The change on the foundations of the Turkish accounting system and the future perspective. Crit. Perspect. Accoun. 2009, 20, 674-679. [CrossRef]

3. Roberts, C.; Weetman, P.; Gordon, P. International Financial Accounting a Comparative Approach; Financial Times Prentice Hall: London, UK, 2002. 
4. Choi, F.; Meek, G. International Accounting; Pearson Prentice Hall: Upper Saddle River, NJ, USA, 2008 ; ISBN 978-0131588141.

5. Nobes, C.; Parker, R. Comparative International Accounting; Financial Times Prentice Hall: London, UK, 2002.

6. Radebaugh, L.H.; Gray, J.S.; Black, E.L. International Accounting and Multinational Enterprises; John Wiley and Sons Inc: Cleveland, NJ, USA, 2006; ISBN 978-0471652694.

7. Klein, R.; Koch, S.; Steinhardt, C.; Strauss, A.K. A review of revenue management: Recent generalizations and advances in industry applications. Eur. J. Oper. Res. 2019, 284, 397-412. [CrossRef]

8. Holland, K.; Lane, J. Perceived auditor independence and audit firm fees. Account. Bus. Res. 2012, 42, 115-141. [CrossRef]

9. Ashbaugh, H.; LaFond, R.; Mayhew, B.W. Do nonaudit services compromise auditor independence? Further evidence. Account. Rev. 2003, 78, 611-639. [CrossRef]

10. Li, C. Does client importance affect auditor independence at the office level? Empirical evidence from going-concern opinions. Contemp. Account. Res. 2009, 26, 201-230. [CrossRef]

11. Kinsey, K.A.; Grasmick, H.G. Did the Tax Reform Act of 1986 improve compliance? Three studies of pre- and post-TRA compliance attitudes. Law Policy 1993, 15, 293-325. [CrossRef]

12. Auerbach, A.J.; Slemrod, J. The economic effects of the Tax Reform Act of 1986. J. Econ. Lit. 1997, 35, 589-632.

13. Guenther, D.A. Earnings management in response to corporate tax rate changes: Evidence from the 1986 Tax Reform Act. Account. Rev. 1994, 69, 230-243.

14. Howard, J.; Sinha, P. Analysts' earnings forecasting behavior surrounding uncertain regulatory events: Evidence from the Tax Reform Act of 1986. Account. Bus. Res. 2020, 50, 35-60. [CrossRef]

15. Morales-Díaz, J.; Zamora-Ramírez, C. The impact of IFRS 16 on key financial ratios: A new methodological approach. Account. Eur. 2018, 15, 105-133. [CrossRef]

16. Yu, J. Investigation of IFRS16 Effect on the Airlines. J. Financ. Account. 2019, 7, 132. [CrossRef]

17. Giner, B.; Pardo, F. The value relevance of operating lease liabilities: Economic effects of IFRS 16. Aust. Account. Rev. 2018, 28, 496-511. [CrossRef]

18. Chow, C.W. The impacts of accounting regulation on bondholder and shareholder wealth: The case of the Securities Acts. Account. Rev. 1983, 58, 485-520.

19. Šimíková, I. Cash Accounting Information System before and after the Amendment to the Act on Accounting as of 2016. Ph.D. Thesis, Slovak University of Agriculture in Nitra, Nitra, Slovak, 2016.

20. Kim, J.E. Amendment of the CPA Act and adoption of division and merger after division of accounting cooperations. Law J. 2020, $69,233-260$.

21. Chandra, U.; Ro, B.T. The role of revenue in firm valuation. Account. Horiz. 2008, 22, 199-222. [CrossRef]

22. Clausing, K.A. The revenue effects of multinational firm income shifting. Tax Notes 2011, 28, 1580-1586. Available online: https:/ / ssrn.com/abstract=2488860 (accessed on 8 February 2013).

23. Kimes, S.E. Revenue management: Advanced strategies and tools to enhance firm profitability. Found Trends Mar. 2015, 8, 1-68. [CrossRef]

24. Chen, C.J.; Liu, X.; Su, X.; Wu, X. Auditor-client bonding and audit quality: Partner-level evidence. Account. Rev. 2009, 70, 193-225.

25. Chi, W.; Huang, H.; Liao, Y.; Xie, H. Mandatory audit partner rotation, audit quality, and market perception: Evidence from Taiwan. Contemp. Account. Res. 2009, 26, 359-391. [CrossRef]

26. Myers, J.; Myers, L.; Omer, T. Exploring the term of auditor-client relationship and the quality of earnings: A case for mandatory auditor rotation? Account. Rev. 2003, 78, 779-799. [CrossRef]

27. Chi, W.; Douthett, E.B., Jr.; Lisic, L.L. Client importance and audit partner independence. J. Account. Public Policy 2012, 31, 320-336. [CrossRef]

28. Chen, C.; Lin, C.; Lin, Y. Audit partner tenure, audit firm tenure, and discretionary accruals: Does long auditor tenure impair earnings quality? Contemp. Account. Res. 2008, 25, 415-445. [CrossRef]

29. Manzon, G.B., Jr.; Smith, W.R. The effect of the Economic Recovery Tax Act of 1981 and the Tax Reform Act of 1986 on the distribution of effective tax rates. J. Account. Public Policy 1994, 13, 349-362. [CrossRef]

30. Kern, B.B. The redistribution of corporate plant and equipment as a result of the Economic Recovery Tax Act of 1981. J. Account. Public Policy 1994, 13, 225-252. [CrossRef]

31. Pilotte, E. The Economic Recovery Tax Act of 1981 and corporate capital structure. Financ. Manag. 1990, 19, 98-107. [CrossRef]

32. Miyagiwa, K. The 2011 America Invents Act: Does it undermine innovation? J. Econ. Manag. Strategy 2015, 24, 211-227. [CrossRef]

33. McWilliams, K. America Invents Act may reinvent R\&D information management practices. Res. Technol. Manag. 2012, 55, 2-3.

34. Chodorow-Reich, G.; Feiveson, L.; Liscow, Z.; Woolston, W.G. Does state fiscal relief during recessions increase employment? Evidence from the American Recovery and Reinvestment Act. Am. Econ. J. Econ. Policy 2012, 4, 118-145. [CrossRef]

35. Pathman, D.E.; Konrad, T.R. Growth and changes in the national health service corps (NHSC) workforce with the American Recovery and Reinvestment Act. J. Am. Board Fam. Med. 2012, 25, 723-733. [CrossRef]

36. Blouin, J.; Krull, L. Bringing it home: A study of the incentives surrounding the repatriation of foreign earnings under the American Jobs Creation Act of 2004. J. Account. Res. 2009, 47, 1027-1059. [CrossRef]

37. Faulkender, M.; Petersen, M. Investment and capital constraints: Repatriations under the American Jobs Creation Act. Rev. Financ. Stud. 2012, 25, 3351-3388. [CrossRef] 
38. Kaysen, C. Collusion under the Sherman Act 1. Q. J. Econ. 1951, 65, 263-270. [CrossRef]

39. Roberts, R.W.; Bobek, D.D. The politics of tax accounting in the United States: Evidence from the Taxpayer Relief Act of 1997. Account. Org. Soc. 2004, 29, 565-590. [CrossRef]

40. Ely, T.L.; Calabrese, T.D. Leveling the playing field: The Taxpayer Relief Act of 1997 and tax-exempt borrowing by nonprofit colleges and universities. Natl. Tax J. 2016, 69, 387-412. [CrossRef]

41. Heuson, A.; Painter, G. The impact of the Taxpayer Relief Act of 1997 on housing turnover in the U.S. Single-Family residential market. Real Estate Econ. 2014, 42, 869-899. [CrossRef]

42. Kroszner, R.S.; Rajan, R.G. Is the Glass-Steagall Act justified? A study of the US experience with universal banking before 1933. Am. Econ. Rev. 1994, 84, 810-832.

43. Filson, D.; Olfati, S. The impacts of Gramm-Leach-Bliley bank diversification on value and risk. J. Bank. Financ. 2014, 41, 209-221. [CrossRef]

44. Sheffet, M.J. The Foreign Corrupt Practices Act and the Omnibus Trade and Competitiveness Act of 1988: Did they change corporate behavior? J. Public Policy Mark. 1995, 14, 290-300. [CrossRef]

45. DeZoort, F.T.; Hermanson, D.R.; Houston, R.W. Audit committee member support for proposed audit adjustments: Pre-SOX versus post-SOX judgments. Audit. J. Pract. Theory 2008, 27, 85-104. [CrossRef]

46. DeFond, M.L.; Lennox, C.S. The effect of SOX on small auditor exits and audit quality. J. Account. Econ. 2011, 52, 21-40. [CrossRef]

47. Huang, H.W.; Raghunandan, K.; Rama, D. Audit fees for initial audit engagements before and after SOX. Audit. J. Pract. Theory 2009, 28, 171-190. [CrossRef]

48. Craswell, A.T.; Francis, J.R.; Taylor, S.L. Auditor brand name reputations and industry specializations. J. Account. Econ. 1995, 20, 297-322. [CrossRef]

49. Francis, J.R. The effect of audit firm size on audit prices. J. Account. Econ. 1984, 6, 133-151. [CrossRef]

50. Francis, J.R.; Stokes, D.J. Audit prices, product differentiation, and scale economies: Further evidence from the Australian market. J. Account. Res. 1986, 24, 383-394. [CrossRef]

51. Palmrose, Z.V. Audit fees and auditor size: Further evidence. J. Account. Res. 1986, 24, 97-110. [CrossRef]

52. Simunic, D.A.; Stein, M.T. Product Differentiation in Auditing: Auditor Choice in the Market for Unseasoned New Issues; Canadian Certified General Accountants' Research Foundation: Vancouver, BC, Canada, 1987.

53. Chang, H.; Cheng, C.A.; Reichelt, K.J. Market reaction to auditor switching from Big 4 to third-tier small accounting firms. Audit. J. Pract. Theory 2010, 29, 83-114. [CrossRef]

54. Van der Cruijsen, C.; de Haan, J.; Jansen, D.J.; Mosch, R. Knowledge and opinions about banking supervision: Evidence from a survey of Dutch households. J. Financ. Stab. 2013, 9, 219-229. [CrossRef]

55. Weisbrod, B.A. Investing in human capital. J. Hum. Resour. 1966, 1, 5-21. [CrossRef]

56. Palmer, S.; Raftery, J. Opportunity cost. BMJ 1999, 318, 1551-1552. [CrossRef]

57. Hiltebeitel, K.M.; Leauby, B.A. Migratory patterns of entry-level accountants. CPA J. 2001, 71, 54-56.

58. Stimpson, J. Staffing solutions. Pract. Account. 1999, 32, 34-42.

59. Yang, C.C.; Tsai, T.Y.; Fu, C.J. Human capital and knowledge spillover effect: Evidence from Taiwan's CPA firms. Sun Yat-Sen. Manag. Rev. 2010, 18, 251-279.

60. Greene, W.H. Econometric Analysis, 8th ed.; Pearson Education: White Plains, NY, USA, 2018; ISBN 978-0134461366.

61. Christensen, L.R.; Greene, W.H. Economies of scale in U.S. electric power generation. J. Political Econ. 1976, 84, 655-676. [CrossRef]

62. Darrough, M.N.; Heineke, J.M. The Multi-output Translog Production Cost Function: The Case of Law Enforcement Agencies; NorthHolland Publishing Company: Amsterdam, The Netherlands, 1978.

63. Molyneux, P.; Thornton, J.; Llyod-Williams, D.M. Competition and market contestability in Japanese commercial banking. J. Econ. Bus. 1996, 48, 33-45. [CrossRef]

64. Kumbhakar, S.C.; Asche, F.; Roll, K.; Tveteras, R. A General Error Revenue Function Model with Technical Inefficiency: An Application to Norwegian Fishing Trawler; Springer International Publishing: Cham, Switzerland, 2016; ISBN 978-3319232270.

65. Banker, R.D.; Chang, H.; Cufnningham, R. The public accounting industry production function. J. Account. Econ. 2003, 35, 255-281. [CrossRef]

66. Berndt, E.R.; Christensen, L.R. The translog function and the substitution of equipment, structures, and labor in U.S. manufacturing 1929-1968. J. Econom. 1973, 1, 81-114. [CrossRef]

67. Shephard, R.W. Theory of Cost and Production Functions; Princeton University Press: Princeton, NJ, USA, 1970.

68. Coelli, T.J.; Rao, D.S.P.; O’Donnell, C.J.; Battese, G.E. An Introduction to Efficiency and Productivity Analysis; Springer Science \& Business Media, LLC. Publisher: Berlin, Germany, 2005; ISBN 978-0387242651.

69. Lee, C.W.; Liu, C.W.; Wang, T.C. The 150-Hour Rule. J. Account. Econ. 1999, 27, 203-228.

70. Liu, C. Legal Liability, Human Capital Investment, and Audit Quality. Ph.D. Thesis, University of National Taiwan University, Taipei, Taiwan, 1997.

71. Meinhardt, J.; Moraglio, J.F.; Steinberg, H.I. Governmental audits: An action plan for excellence. J. Account. 1987, 164, 86-91.

72. Financial Reporting Council (FRC). Discussion Paper: Promoting Audit Quality. 2006. Available online: http://www. frcpublications.com (accessed on 8 February 2002).

73. Aldhizer, G.R.; Miller, J.R.; Moraglio, J.E. Common attributes of quality audits. J. Account. 1995, 1, 61-71. 
74. Schmidt, F.L.; Hunter, J.E.; Outerbridge, A.M. Impact of job experience and ability on job knowledge, work sample performance, and supervisory ratings of job performance. J. Appl. Psychol. 1986, 71, 432-439. [CrossRef]

75. Fasci, M.A.; Valdez, J. A Performance contrast of male- and female-owned local accounting practices. J. Small Bus. Manag. 1998, $36,1$.

76. Chen, Y.S.; Chang, B.G.; Lee, C.C. The association between continuing professional education and financial performance of public accounting firms. Int. J. Hum. Resour. Manag. 2008, 19, 1720-1737. [CrossRef]

77. Downey, L.A.; Lee, B.; Stough, C. Recruitment consultant revenue: Relationships with IQ, personality, and emotional intelligence. Int. J. Select. Assess. 2011, 19, 280-286. [CrossRef]

78. Collins-Dodd, C.; Gordon, I.M.; Smart, C. Further evidence on the role of gender in financial performance. J. Small Bus. Manag. 2004, 42, 395-417. [CrossRef]

79. Bröcheler, V.; Maijoor, S.; Witteloostuijn, A.V. Auditor human capital and audit firm survival: The Dutch audit industry in 1930-1992. Account. Organ. Soc. 2004, 29, 627-646. [CrossRef]

80. Elder, R.J.; Beasley, M.S.; Arens, A.A. Auditing and Assurance Services: An Integrated Approach, 12th ed.; Pearson Education: Upper Saddle River, NJ, USA, 2008; ISBN 978-0136128274.

81. Yang, C.C.; Chen, Y.S.; Chen, J.X. Investigation of the differences in the life cycle functions of accounting firms of different sizes. In Proceedings of the American Accounting Association the 2020 Annual Meeting, Atlanta, GA, USA, 10-13 August 2020.

82. O'Keefe, T.B.; Simunic, D.A.; Stein, M.T. The production of audit services: Evidence from a major public accounting firm. J. Account. Res. 1994, 32, 241-261. [CrossRef]

83. Texas Society of Certified Public Accountants. Management of an Accounting Practice Survey; Dallas Texas Publishing: Dallas, TX, USA, 2000. 